\title{
Opportunities and Challenges for MBBS Education of Human Parasitology under the Background of One Belt and One Road
}

\author{
Weiqun Wang1, Lili Tang2, Ji Zheng ${ }^{3}$, Jianfa Liu ${ }^{3 *}$ \\ ${ }^{1}$ Department of Pathogen Biology and Immunology, Kunming Medical University, Kunming, China \\ ${ }^{2}$ Department of Pathogen Biology, Guangxi Medical University, Nanning, China \\ ${ }^{3}$ Department of Pathogen Biology, Medical School of Ningbo University, Ningbo, China \\ Email: *liujianfa@nbu.edu.cn
}

How to cite this paper: Wang, W.Q., Tang, L.L., Zheng, J. and Liu, J.F. (2019) Opportunities and Challenges for MBBS Education of Human Parasitology under the Background of One Belt and One Road. Open Access Library Journal, 6: e5756. https://doi.org/10.4236/oalib.1105756

Received: September 2, 2019

Accepted: September 21, 2019

Published: September 24, 2019

Copyright $\odot 2019$ by author(s) and Open Access Library Inc.

This work is licensed under the Creative Commons Attribution International License (CC BY 4.0).

http://creativecommons.org/licenses/by/4.0/

\begin{abstract}
The "One Belt and One Road" initiative raises new requirements on international education of China's colleges and universities. For historical and cultural reasons, colleges and universities in China are facing both opportunities and challenges in human parasitology teaching for Bachelor of Medicine-Bachelor of Surgery (MBBS) students. We shall keep up with the pace of the time, and provide education with Chinese characteristics by expanding and changing our teaching ideas. Under the guidance of the "Belt and Road" initiative, we shall continuously develop the education and teaching of human parasitology for international MBBS students, improve international competitiveness and influence, promote the international process of China's education and teaching of human parasitology and make a contribution to the higher education and teaching of China.
\end{abstract}

\section{Subject Areas \\ Education, Public Health}

\section{Keywords}

Belt and Road, Human Parasitology, MBBS, Opportunities and Challenges

\section{Introduction}

In his visit to Middle Asia and South East countries in 2013, President Xi Jinping proposed the Silk Road Economic Belt initiative and the $21^{\text {st }}$ Century Maritime Silk Road initiative (abbreviated as "B \& R") in succession. At present, there are 
65 One Belt and One Road countries for attending. The Silk Road Economic Belt extends on land in three directions: 1) from China via Middle Asia and Russia to Europe; 2) from China via Middle Asia, West Asia to the Persian Gulf and Mediterranean Sea, and 3) from China to South East Asia, South Asia and the Indian Ocean. The $21^{\text {st }}$ Century Maritime Silk Road extends mainly along two routes, of which one is from China's coastal ports via South China Sea to the Indian Ocean and further to Europe, and another one is from China's coastal ports via South China Sea to the South Pacific. The Belt and Road initiative covers a total population of 4.4 billion and an economic aggregate of approximately 21 trillions US dollars [1].

The world today is experiencing complex changes. To jointly construct the Belt and Road is of the fundamental interests of the international community and reflects the common idea and pursuit of human beings. This initiative is an active exploration of new modes of international cooperation and global governance and adds new positive energy to the peaceful development of the world. Under this background, human parasitology education for international MBBS students has become an important part of China's higher education as an important indicator reflecting the teaching level of higher education [2]. Human parasitology, also called medical parasitology, is a science studying the morphological structure, development and proliferation of parasites related to medicine, the relations between parasites and the human body and external environment, and the diagnosis and prevention of parasitic diseases [3]. It is a bridging course that connects basic medicine and clinical medicine and a mandatory course for international students in medical universities of China. According to statistics of the Ministry of Education of the People's Republic of China, an increasing number of international students, including 317,200 from the Belt and Road countries, are studying in China. As of 2017, international students from 204 countries and regions are studying in 935 universities and colleges of China [4] [5]. Under the background of the Belt and Road initiative, the globalization of China's higher education has become an inevitable trend, which provides a great opportunity for internationalization of China's higher education. Meanwhile, international exchange and cooperation in education have been improved to the level of national strategy and a clear direction and higher requirements have been set for reform of higher education and teaching, bringing a giant challenge for China's higher education [6]. To meet the goal and requirement of internationalization, for human parasitology education and teaching in universities and colleges of China, we shall update our education and teaching ideas, strengthen the teaching level of teachers and build a reasonable internationalized teaching management system on the basis of characteristics of the discipline. We shall gradually improve the professional capabilities of international MBBS students in human parasitology, promote international exchange and cooperation and compliance with international standard, and foster more international students who "know about China, are friendly to China, pro-China and love China". 


\section{Opportunities of Human Parasitology Education for International MBBS Students}

China has an increasing international influence on human parasitology education for international MBBS students and thus more and more international students come to study in China. According to statistics of the Ministry of Education, the number of international students in China hit 489,200 in 2017 and China has become the largest destination country of Asian international students. Under the Belt and Road initiative, the number of international students from Belt and Road countries has the most significant growth and achieved 317,200 , accounting for $64.85 \%$ of all international students in China. This means that internationalization and globalization of education have become the inevitable trend for China in the new century. Human parasitology education for international MBBS students in China shall take this opportunity to actively engage in international exchange and cooperation so as to adapt to the trend of internationalized education. Many provinces of China border Belt and Road countries, including India, Laos, Thailand, Nipper and Vietnam. An increasing number of international students from these countries are coming to study in China. This is a regional advantage to recruit students from these countries.

\section{Challenges in Human Parasitology Education for International MBBS Students}

The scale of enrollment of international students keeps expanding in China. This creates new opportunities as well as challenges for universities and colleges of China in human parasitology education for international MBBS students.

1) Teaching staff is not been effectively constructed for human parasitology education for international MBBS students in China.

Teachers are the primary instructors of teaching activities. The teaching level of teachers has a direct influence on the quality of teaching and education for international students in China. At present, there are still many problems with the construction of teaching staff for human parasitology education for international MBBS students. One of the major problems is the low English proficiency of teachers of human parasitology and the heavy accent of students from some countries, where English is the native language. The teaching of human parasitology is mainly undertaken by young teachers with certain level of English proficiency. However, they are not fully ready in thought and language proficiency and have certain difficulty in listening and speaking English. Undoubtedly, this is a major barrier for teaching and communicating with international students [7] [8]. To overcome such barriers, in some cases, universities have to employ foreign teachers to complete teaching tasks.

2) Difference in prevalence of parasitic diseases

A major characteristics of human parasitology is "endemicity". Different cultural background, geographic environment, climate conditions and medical level lead to dramatic difference in parasitic diseases among China and the source 
countries of international students. Different regions have different religious beliefs. For example, students from South East Asia countries may believe in Buddhism, Islamism or Christianity. Besides difference in religious beliefs, international students also have different taboo. For example students from Pakistan do not eat pork for reason of Muslim pork taboo. Therefore, people in Pakistan are not likely to be affected by Taenia solium. Another example is schistosomiasis. In China, there is only Schistosoma japonicum, but in some source countries of international students, there are Schistosoma mansoni and Schistosoma haematobium. Filariasis has been well controlled in China but is still prevalent in source countries of some international students. The common and frequently-occurring parasitic diseases seen in China by the international students are different from those in their own countries, so they cannot apply what they learn about the parasitic diseases in China when they return to their countries.

3) Lack of systematic human parasitology courses system for international students

In China, the system of human parasitology courses for international students is not complete. The teaching mode and management mode are relatively backward. In most cases, the system of courses for Chinese students is applied to international students, and thus lacks of pertinence and rationality [9]. Although China is attaching more importance to the construction of courses for international students, but the intensity and extensity still cannot meet the need of international students' education. The teaching content, progress and assessment of human parasitology courses are not unified. Textbooks of human parasitology, as an important part of teaching activities, are an essential guarantee of teaching quality [10]. However, so far there is no unified textbook in English for human parasitology. The content of human parasitology keeps updating, while some of the contents of textbooks have been out of date. Compilation of practical textbooks of human parasitology is a time and labor consuming task, which cannot be completed by any single university or college.

\section{Measures to Improve Parasitology Education for MBBS International Students}

First, teachers of human parasitology education for international MBBS students shall improve their English proficiency, particularly proficiency in specialized English for human parasitology and the ability in oral English expression. In addition to effort by teachers on their own part, universities and colleges shall strengthen English language training for teachers by sending selected teachers to receive systematic training. Second, we shall understand, respect and hold an open attitude toward the cultural background of the sources countries of international students. Third, teachers of human parasitology shall know well about the prevalence of human parasitic diseases in the sources countries of international students, master knowledge about these diseases and tailor the courses for international MBBS students so that they can apply what they learn in China af- 
ter returning to their countries. Lastly, Theoretic and experiment textbooks in English shall be compiled for international students in reference to foreign teaching programs and textbooks originally published in English, in combination with the specific features and demands of international students.

\section{Perspectives}

Parasitic diseases have always been a general public health problem worldwide [11]. After the Belt and Road initiative was put forward, more and more international students from the Belt and Road counties are coming to study in China. This brings unprecedented opportunities for China's human parasitology education for international MBBS students. Meanwhile, we also need to consider how to improve the quality of teaching and education for international students and inspire their interests and activity in learning by offering courses tailored on the basis of specific situation of parasitic diseases in their countries. Teaching of human parasitology shall be carried out with emphasis on endemic parasitic diseases and construction of teaching and talents in human parasitology education for international students in China shall be improved to serve the national strategy by grasping the opportunities brought along by the Belt and Road initiative [12]. Although many new problems and challenges will be met, surely they will finally be solved through persistent effort, innovation and reform.

\section{Funding}

Supported by grant of the Teaching research on MBBS in Medical School of Ningbo University.

\section{Conflicts of Interest}

The authors declare no conflicts of interest regarding the publication of this paper.

\section{References}

[1] Wang, Y.-K. (2015) One Belt and One Road": Opportunities and Challenges. People's Publishing House, Beijing.

[2] Chen, J.-L., Zhu, D.-D. and Duan, Y.-N. (2013) A Study on Teaching Human Parasitology in English for International Students. Basic Medical Education, 15, 434-436.

[3] Wang, G.-X. and Wang, H. (2019) Medical Parasitology. Higher Education Press, Beijing.

[4] Ministry of Education (2018) Works on International Students in China Develops toward Higher Level and High Quality.

[5] Wang, J. (2018) Education for International Students under the "One Belt and One Road" Initiative. China Scholars Abroad, No. 7, 24-25.

[6] Ji, X. (2019) A Study on the Construction of Courses for International Students in China under the One Belt and One Road Initiative. Educational Research, No. 5, 30-31. 
[7] Wan, X.-H. (2002) Skills for Communication and Educating Patients Are Important Content of Medical Education. Journal of Nanjing Medical University: Social Science Edition, No. 3, 42-43.

[8] Zhao, Q. (2014) An Analysis on Problems and Measures for Management of International Students in Universities and Colleges of China. Science Education Article Collects, No. 2, 205-206.

[9] Zhang, D.-H. and Chen, L. (2012) Valuing Cultural Diversities of International Medical Students and Improving the Teaching Quality of Human Parasitology. Nanjing Medical University: Social Science Edition, 53, 490-492.

[10] Wang, S.-H., Zhu, X.-P. and Yang, J. (2012) A Preliminary Study on How to Improve the Quality of Human Parasitology Teaching for International Students. Basic Medical Education, 14, 229-230.

[11] National Development and Reform Commission, Ministry of Foreign Affairs, and Ministry of Commerce of the People's Republic of China (2015) Vision and Action Plan on the China-Proposed Belt and Road Initiative. People's Publishing House, Beijing.

[12] Yang, G. and Jing, C.-X. (2016) A Few Thoughts on Reform of Human Parasitology Teaching in Universities for Overseas Chinese under the Background of One Belt and One Road initiative. Journal of Tropical Medicine, 16, 544-545. 